\title{
Contextualizing the 2016 State Duma Election
}

Derek S. Hutcheson

Malmö University, Sweden

derek.hutcheson@mah.se

To cite: Derek S. Hutcheson (2017), 'Contextualizing the 2016 State Duma Election', Russian Politics 2(4): 383-410. [ISSN: 2451-8913]

Note that this is the submission manuscript and that there may be minor differences between this and the final published version, as typeset and copy-edited by Brill Publishing. The definitive version of the article can be found at: http://booksandjournals.brillonline.com/content/journals/10.1163/2451-8921-00204001.

\begin{abstract}
An overview is given of the 2016 Russian State Duma election, and its significance for the current Russian regime. As the first in a series of five articles in this edition of Russian Politics, it sets the 2016 State Duma election into context. It begins by discussing the role of the Duma in Russian politics, and reviews political developments between the protests that followed the 2011 parliamentary election, and the successful conclusion of the 2016 one. It then examines how institutional and political changes came together in the 2016 campaign. The resultant supermajority for the pro-Kremlin United Russia party is analyzed, before the remaining articles in this issue - which examine the issues of turnout, voting behavior, electoral manipulation and the future of the regime - are introduced.
\end{abstract}

\section{Keywords:}

Russia - State Duma - Election - Parties - Voting behavior 


\section{Introduction}

The 2016 State Duma election was significant for being the first major nationwide electoral test for the Russian authorities since the return of Vladimir Putin to the presidency in 2012 - and a key indicator of the extent to which they had maintained and consolidated their control over the political system.

The previous election, in December 2011, held in the last months of Dmitrii Medvedev's one-term presidency, was marred by controversy. The results were protested through mass demonstrations on a scale not seen since the mid-1990s. Five years on, the 2016 State Duma election proceeded virtually without incident. The result was a supermajority for the United Russia party, and the secure retention of the Kremlin's control over the national legislature until 2021. It also paved the way for the re-election (or smooth succession) of the Putin regime in the significant 2018 presidential election.

How this came about, and what it means, is the subject both of this article and of this edition of Russian Politics more generally. ${ }^{1}$ This article sets the 2016 State Duma election into context. It begins by discussing the role of the Duma in Russian politics, and reviews political developments during the five years between the two elections. It then examines how institutional and political changes came together in the 2016 State Duma campaign. The results are analyzed, before the remaining articles in this issue - which examine the election in more depth - are introduced.

\section{The State Duma in Russian Politics}

\section{The Role of the State Duma}

The State Duma, the elected chamber of Federal Assembly, is not a particularly powerful parliament by international standards. Constitutionally, it plays a subordinate role to the directly-elected president, and parliamentary elections do not directly impact upon the composition of government. ${ }^{2}$ Whilst it has several powers to hold the president to account

\footnotetext{
${ }^{1}$ We are grateful to Prof. Neil Robinson (University of Limerick) for acting as referee for the collection of articles, and for his constructive comments and suggestions. Earlier versions of the papers were given at the British Association for Slavic and East European Studies (BASEES) conference, University of Cambridge, 31 March-2 April 2017.

${ }^{2}$ Constitution of the Russian Federation, Art. 97.3, http://www.consultant.ru/document/cons_doc_LAW_28399/ (accessed 31 August 2017).
} 
(such as giving its approval to appoint a new prime minister), many of these safeguards are counterbalanced by presidential overrides.

The primary impetus of Russian politics therefore comes from its powerful presidency - an office that has been occupied for all but four years since 2000 by Vladimir Putin. Over time, the State Duma's role has been reduced to that of a legislative conveyor belt. Whereas the oppositionist II State Duma (1995-1999) examined an average of 416 bills and passed 261 laws per year, the VI convocation (2011-16) averaged 1,017 bills and 463 laws per annum indicating that many laws received only a few minutes' cursory scrutiny. Nor does it contradict the presidential administration frequently: 99.8 percent of laws that emerged from the Federal Assembly in the 2008-16 period received the signature of Presidents Dmitrii Medvedev or Vladimir Putin, compared with only around 70 percent under President Yeltsin in $1995-99 .^{3}$

But this does not mean that study of Russia's parliamentary elections is unimportant. The legislature forms an integral part of the political system and the machinery of governance, and - as Yeltsin discovered - it can considerably circumscribe presidential power unless there is a pro-presidential majority. ${ }^{4}$ It is precisely for this reason that the Putin (and Medvedev) administrations have put so much energy into creating and maintaining the institutional and party vehicles to control the legislative agenda.

Russia's seven parliamentary elections have often assumed a significance that has gone beyond their formal purpose of electing a legislature for the next term. From 1995 to 2011, they were held shortly before the next scheduled presidential elections. This meant that they acted as unofficial "primary" contests. The disastrous showing of the pro-Kremlin parties gave a sharp wake-up call to the Yeltsin campaign in December 1995, paving the way for its eventual victory in summer 1996. In 1999, the State Duma election was a proxy battleground for the vicious intra-elite fight to succeed Yeltsin the following year. In 2003, after considerable electoral and institutional engineering, the election marked the consolidation of the first pro-Kremlin majority in the State Duma. The 2007 and 2011 parliamentary elections,

\footnotetext{
${ }^{3}$ Statistics calculated by the author based on information available on the State Duma's website: http://www.duma.gov.ru/legislative/statistics/, accessed 22 August 2017.

${ }^{4}$ Paul Chaisty and Jeffrey Gleisner, “The Consolidation of Russian Parliamentarism: The State Duma, 1993-8”, in Neil Robinson ed. Institutions and Political Change in Russia (Basingstoke: Palgrave Macmillan, 2000): 4168; Thomas F. Remington, The Russian Parliament: Institutional Evolution in a Transitional Regime, 1989-99 (New Haven/London: Yale University Press, 2001).
} 
in turn, laid the ground for the swap of the presidency from Vladimir Putin to Dmitrii Medvedev and back again. ${ }^{5}$

Looked at in a wider context, Russian parliamentary elections from 1993 to 2011 can effectively divided into two phases. From 1993 to 2003, a bewildering array of hopeless organizations appeared and disappeared from the electoral menu - hence Rose et al.'s characterization of it as a "floating” party system. ${ }^{6}$ This weak institutionalization was targeted by the Putin administration’s earliest reforms after 2000. More stringent rules on party registration, restrictions on the organizations that were entitled to participate, and a concerted effort on the Kremlin's party to consolidate the centrist State Duma factions and coopt regional political machines led to the start of the second, consolidated phase of the State Duma's existence. From having one of the world's least stable party systems, Russian has for the last decade had one of the least volatile. UR has won a plurality or absolute majority of the vote in every State Duma election since 2003, and held a parliamentary majority throughout. The constellation of parties that emerged from the 2016 State Duma election was more or less identical to the one that has existed since 2007. On each of these occasions, UR has formed the majority, with three small factions in nominal opposition - the Communist Party of the Russian Federation (CPRF), Liberal Democratic Party of Russia (LDPR) and A Just Russia $(\mathrm{AJR}){ }^{7}$

\section{Political Developments During the VI State Duma Convocation (2011-16)}

As noted above, significant concerns were raised about the legitimacy of the 2011 State Duma election. Anecdotal accounts of pressure to vote and irregularities in procedures

\footnotetext{
${ }^{5}$ Putin, the senior partner in the so-called “tandem” arrangement, stood down in 2008 to avoid contravening the constitutional ban on serving more than two consecutive terms in office (2000-04 and 2004-08). He retained de facto control over Russia's governance from the subordinate office of prime minister, before returning to the Kremlin for a new "first term” in 2012 and appointing outgoing President Medvedev as prime minister.

${ }^{6}$ Richard Rose, Neil Munro and Stephen White, “Voting in a Floating Party System: The 1999 Duma Election”, Europe-Asia Studies 53, no. 3 (2001): 419-43.

7 The LDPR and CPRF are Russia’s longest-standing parties. They have been represented in every State Duma convocation since 1993. The LDPR, famous for its leader Vladimir Zhirinovsky’s firebrand nationalist rhetoric but generally loyal to the regime, came first in the 1993 party list part of the election. The CPRF, led by Gennadii Zyuganov since its inception, won the plurality of votes in 1995 and 1999 but lost support after the turn of the century. It has developed a niche as a small but emasculated within-system opposition party. AJR was a pro-Kremlin party formed in time for the 2007 State Duma election. For more on the Russian party system, see David White, “Re-conceptualising Russian Party Politics”, East European Politics 28, no. 3 (2012): 210-224.
} 
were mirrored in observers’ reports. ${ }^{8}$ In the final count, UR came just a few fractions of a percentage point short of winning exactly 50 percent of the vote. When President Medvedev (who had headed UR's election list) jokingly said a few days after the election that the chairman of the Central Electoral Commission (CEC), Vladimir Churov, was "practically a magician”, cynics thought that some region's results may indeed have owed more to sorcery than voters. ${ }^{9}$ Within a few days, thousands of protesters were on the streets under the rallying call “For Fair Elections!”. Two Moscow protests in particular - on Bolotnaya Square on 10 December 2011 and Prospekt Sakharova on 24 December - attracted large crowds of between 25,000 and 55,000. ${ }^{10}$ Many of the protestors seemed to be middle class and politically engaged. ${ }^{11}$

The authorities were initially slow to realize the import of the demonstrations. At first (prime minister) Vladimir Putin mocked the protesters' lapel badges by comparing them with contraceptives. ${ }^{12}$ But the protests had shown "cracks in the wall” of the succession plan, ${ }^{13}$ and Medvedev quickly sought to reframe people's demands on the authorities as evidence of

\footnotetext{
${ }^{8}$ OSCE/ODIHR, Russian Federation. Elections to the State Duma. 4 December 2011. OSCE/ODIHR Election Observation Mission Report (Warsaw: ODIHR, 2012), http://www.osce.org/odihr/86959 (accessed 3 September 2017); A.Yu. Buzin, V.S. Vakhshtain, A.V. Kynev, A.Yu. Lyubarev, Yu.A. Nisnevich and M.I. Savintseva, Federal'nye, regional'nye i mestnye vybory v Rossii 4 dekabrya 2011 goda. Analiticheskii doklad (Moscow: Golos, 2012).

${ }^{9}$ TASS, “Glava TsIK soobshchil Medvedu rezultaty vyborov po itogam obtraboki 99,9 protsentov byulletenei”, 6 December 2011, http://tass.ru/glavnie-novosti/514079 (accessed 3 September 2017).

${ }^{10}$ Exact figures are hard to verify, and the organizers claimed higher numbers than the authorities. The 25,000 to 50,000 figure is estimated based on crowd density and surface area on Prospekt Sakharova [RIA-Novosti “Skol'ko chelovek mozhet vmestit' prospect Sakharova v Moskve”, 23 December 2011, https://ria.ru/infografika/20111223/524373513.html (accessed 1 September 2017)]. The Bolotnaya Square protest on 10 December 2011 had been licenced for 30,000 people, but anonymous "employees of the police force" were quoted in opposition media estimating the crowd at 100,000 [Elena Kostyuchenko, "Bolotnaya Ploshchad >100000”, Novaya Gazeta, 11 December 2011, https://www.novayagazeta.ru/news/2011/12/10/52372-bolotnaya-ploschad-100000 (accessed 7 September 2017)].

${ }^{11}$ Levada-Center, “Opros na prospekte Sakharova 24 dekabrya”, 26 December 2011, http://www.levada.ru/2011/12/26/opros-na-prospekte-saharova-24-dekabrya/ (accessed 1 September 2017). 12 “Liniya Putina: Prem’er otvetil na voprosy rossiyan”, Rossiiskaya Gazeta, 16 December 2011, https://rg.ru/2011/12/16/liniya.html (accessed 1 September 2017).

${ }^{13}$ Vladimir Gel'man, “Cracks in the Wall: Challenges to Electoral Authoritarianism in Russia”, Problems of Post-Communism 60, no. 2 (2013): 3-10.
} 
Russia’s “maturing democracy” and acknowledge their concerns by proposing a raft of electoral reforms (discussed further below). ${ }^{14}$ This acknowledgement, combined with the protesters' lack focused leadership, meant that the “For Free Elections!” movement gradually lost steam. Three months after the Duma election, Vladimir Putin secured 64 percent of the vote to win re-election to the presidency, visibly relieved to have weathered the brief storm of protest, and he commenced his third term in the Kremlin ceremonially on 7 May 2012.

In the four years that followed, Russia gained much attention both for its international activities and for domestic reforms. The transfer of Crimea in March 2014 from Ukraine to Russia - without the former's consent- was arguably one of the most significant international relations events of recent times. Despite being strongly condemned by the international community, leading to sanctions, by the time of the 2016 election Crimea had become a de facto part of the Russian Federation's institutional structure. ${ }^{15}$ In addition, the covert war in eastern Ukraine, and Russia's decisive intervention in the civil war in Syria in 2015, were further signs of the country’s increased international assertiveness.

Domestically, the priority was to ensure that the 2011-12 scenario would not be repeated, through a combination of restrictive policies to discourage dissent, populist policies to bolster public support, and reforms to increase electoral legitimacy and pre-empt objections. The VI Duma convocation (2011-16) attracted a reputation as a "rabid printer" of poorly-drafted reactionary laws, often with cross-party support. ${ }^{16}$ In addition to nearunanimous support for the incorporation of Crimea, other initiatives that attracted attention included an increase in fines for non-observation of the rules on picketing, the creation of a register of prohibited websites, and the right of state inspectors to blockade websites that were perceived to be calling for riots or unrest. ${ }^{17}$ UR deputies, headed by Irina Yarovaya, pushed through two anti-terrorism packages that were also be seen as potentially restrictive of

\footnotetext{
${ }^{14}$ Dmitrii Medvedev, “Address to the Federal Assembly”, http://en.kremlin.ru/events/president/news/14088, 22 December 2011 (accessed 4 September 2017).

${ }^{15}$ Nikolai Petrov, “Crimea”, Russian Politics and Law 54, no. 1 (2016): 74-95.

${ }^{16}$ Maria Epifanova and Aleksandr Mineev, “Vzbesivshiisya printer v roli gaechnogo klyucha”, Novaya Gazeta, 9 July 2014, https://www.novayagazeta.ru/articles/2014/07/05/60224-vzbesivshiysya-printer-v-roli-gaechnogoklyucha (accessed 3 September 2017).

${ }^{17}$ Andrei Vinkurov, Artur Gromov and Igor’ Kryuchkov, “Duma otzapreshchalas””, Gazeta.ru, 24 June 2016, https://www.gazeta.ru/politics/2016/06/24_a_8324543.shtml (accessed 3 September 2017).
} 
political debate, as well as of genuine terrorism. ${ }^{18}$ Other laws drew on the narrative that the 2011-12 protests had been encouraged by the West. There were to be stiff new penalties for failure to declare dual nationality; and NGOs that received any foreign funding and engaged in (broadly defined) political activity could be reclassified as sinister-sounding "foreign agents”, with restrictions on their activities. Several high-profile prosecutions of artistic dissenters were also carried out through the legal system.

The less reactionary side of the Duma's legal reforms concerned the electoral process. The most substantial changes involved a shift of electoral system to the State Duma, discussed below. Other measures included a liberalization of party registration rules and a return of gubernatorial elections - but under controlled conditions. Although one UR candidate - in Irkutsk - lost in 2015 to the CPRF, it was difficult for complete outsiders to enter the gubernatorial races because of a 'municipal filter'. ${ }^{19}$ This that meant candidates had to collect signatures and have support from members of local authorities across large parts of the regions in question before being registered. ${ }^{20}$

\section{The institutional changes}

\section{The System}

One of the primary innovations for the 2016 election campaign was a substantial revision of the electoral system. Schedler highlights the "two levels of struggle" that take place in a typical electoral authoritarian regime between ruler and opposition - over the rules

18 Federal Law “O vnesenii izmenenii v Federal'nyi zakon 'O protivodeistvii terrorizmu' i otdel'nye zakonodatel'nye akty Rossiiskoi Federatsii v chasti ustanovleniya dopolnitel'nykh mer protivodeystviya terrorizmu i obespecheniya obshchestvennoi bezopasnosti”, Law N374-FZ, 6 July 2016, Sobranie zakondatel'stva Rossiiskoi Federatsii, 11 July 2016, No. 28, Art. 4558; Federal Law “O vnesenii izmenenii v Ugolovnyy kodeks Rossiiskoi Federatsii i Ugolovno-protsessual'nyi kodeks Rossiiskoi Federatsii v chasti ustanovleniya dopolnitel'nykh mer protivodeystviya terrorizmu i obespecheniya obshchestvennoi bezopasnosti”, Law N375-FZ, Sobranie zakondatel’stva Rossiiskoi Federatsii, 11 July 2016, No. 28, Art. 4559.

${ }^{19}$ Grigorii V. Golosov, “The September 2015 Regional Elections in Russia: A Rehearsal for Next Year's National Legislative Races”, Regional \& Federal Studies 26, no. 2 (April 2016): 255-268.

${ }^{20}$ Federal Law “O vnesenii izmenenii v Federal’nyi zakon ‘Ob obshchkh printsipakh organizatsii zakonodatel’nykh (predstavitel’nykh) i ispolnitel’nykh organov gosudarsvetnnoi vlasti sub”ektov Rossiiskoi Federatsii’ i Federal'nyi zakon ‘Ob osnovnykh garantiyakh izbiratel’nykh prav i prava na uchastie v referendume grazhdan Rossiiskoi Federatsii’”, Law N40-FZ, 2 May 2012, Rossiiskaya Gazeta, 2 May 2012. Available online: http://www.rg.ru/printable/2012/05/04/gubernatori-dok.html (accessed 8 September 2017). 
of the game, and within them. ${ }^{21}$ Major electoral reform is relatively rare in developed democracies, because of the presence of multiple veto players and strong traditions. By contrast, if a regime has consolidated control over the legislative agenda, subtle changes in electoral rules can advantage one or more actors over others.

Endless change to the Russian electoral system has become almost endemic. Between the 2003 and 2016 elections, the State Duma law was amended 40 times; the Law on Political Parties (which regulates the affairs of parties, the sole organizations entitled to stand), 36 times, and the Law on Fundamental Guarantees of Electoral Rights - the framework election law - no fewer than 78 times. $^{22}$

The most fundamental change to the electoral system for 2016 concerned the electoral formula. For the last two elections, the State Duma had been elected from closed party lists, based on largest-remainder proportional representation with a 7 percent electoral threshold. ${ }^{23}$ For 2016 it returned to a mixed unconnected system, similar in principle to the one used between 1993 and 2003. The State Duma's 450 elected deputies were elected in two tranches: 225 from party lists, with a 5 percent electoral threshold; and 225 from single-member district (SMD) constituencies. ${ }^{24}$

From 1993-2003, the SMDs were the source of much fragmentation in the party system. Two crucial differences meant that they played a more consolidating role in 2016. First, the party system itself was dominated by one party - UR - giving it the traditional "winners' bonus" generally found in majoritarian systems. ${ }^{25}$ Second, the boundaries of the

\footnotetext{
${ }^{21}$ Andrei Schedler, The Politics of Uncertainty: Sustaining and Subverting Electoral Authoritarianism (Oxford: Oxford University Press, 2013), 112-138.

${ }^{22} \mathrm{An}$ "amendment" is in this case defined as either a wholly new law that supersedes its predecessor, or a legislative act that has the effect of modifying one or more provisions of the existing main law. Some of these have been relatively minor technical changes, while others have been far-reaching effects.

${ }^{23}$ The 2011 electoral system had an unusual provision that parties with between 5 and 7 percent of the vote would be rewarded with a token 1 or 2 seats, not proportionate to their vote. In practice, no party fell into this range.

${ }^{24}$ Law on the Elections to the State Duma, 2016: Federaln'yi zakon “O vyborakh deputatov Gosudarstvennoi Dumy Federal'nogo Sobraniya Rossiiskoi Federatsii”, Federal Law N20-FZ, 22 February 2014, Sobranie zakonodatel'stva Rossiiskoi Federatsii, 24 February 2014, no. 8, Art. 740, with 8 amendments up to 5 April 2016, Art 3. English translation: www.legislationline.org/documents/id/19906 (accessed 4 September 2017). ${ }^{25}$ For the principles of seat division, and constituency maps, see Central Electoral Commission, Vybory deputatov Gosudarstvennoi Dumy Federal'nogo Sobraniya Rossiiskoi Federatsii sedmogo sozyva. 2016.
} 
electoral districts played a role. As in the past, the requirement that boundaries could not cross subjects of the Federation meant that small regions with fewer voters, and medium-sized regions that did not have enough voters to justify two seats, were over- and under-represented, respectively. More significantly, constituency boundaries fanned out from the centers of major cities like slices from the middle of a cake, splitting places such as Rostov-on-Don and Nizhny Novgorod into several parts, and attaching each to contiguous rural districts. This created safer seats for UR, by diluting the urban opposition vote with more pro-UR rural districts, and it was compared by some to the gerrymandering common in United States congressional districts. ${ }^{26}$

The VI Duma convocation was the first to be elected for a 5-year, rather than 4-year term, meaning that it should have ended its term in December 2016. However, the election was brought forward to the earlier date of 18 September 2016, at the behest of three of the four parliamentary factions. ${ }^{27}$ The official justification was to align the State Duma election with the already-planned unified day of voting, and to allow the Duma sufficient time to consider the following year's budget. ${ }^{28}$ However, it also seemingly reflected a change in strategy of the authorities, which had previously relied on strong mobilization of voters and high turnout. The decision to have the campaign take place during the summer holiday period

Elektoral'naya statistika (Moscow: CEC, 2017), 15-117, http://vestnik.cikrf.ru/upload/publications/analytics/statistic 21_04_2017.pdf (accessed 1 September 2017). ${ }^{26}$ Andrei Vinokurov, Natal'ya Galimova and Vladimir Dergachev, “Churov narezal ‘salamandru’”, Gazeta.ru, 2 September 2015, https://www.gazeta.ru/politics/2015/09/02_a_7736963.shtml (accessed 1 September 2017); E.V. Alimov, “Dzherrimendering v sovremennoi Rossii: suchchnost' i perspektivy ispol'zovaniya”, Konstitutionnoe i munitsipal'noe pravo, no. 5 (2016): 59-61.

${ }^{27}$ Federal Law “O vnesenii izmenenii v stat'i 5 i 102 Federal'nogo zakona 'O vyborakh deputatov Gosudarstvennoy Dumy Federal'nogo Sobraniya Rossiiskoi Federatsii’”, Law N 272-FZ, 14 July 2015, Sobranie Zakonodatel'stva Rossiiskoi Federatsii, 20 July 2015, no. 29 (I): Art. 4398, www.consultant.ru/cons/cgi/online.cgi?req=doc\&base $=$ LAW\&n=182723\&fld=134\&dst=1000000001,0\&rnd=0. 5396733007078072\#0 (accessed 30 August 2017).

${ }^{28}$ Committee of the State Duma for Constitutional Law and State Construction, “Poyasnitel'naya zapiska k proektu federal'nogo zakona 'O vnesenii izmenenii v stat'i 5 i 102 Federal’nogo zakona “O vyborakh deputatov Gosudarstvennoy Dumy Federal'nogo Sobraniya Rossiyskoi Federatsii”,”, 15 June 2015, http://sozd.parlament.gov.ru/bill/815174-6 (accessed 30 August 2017). 
meant that well-resourced urban Russians would be away from home, and thus be less likely to mobilize into anti-authority protest - and less likely to pay much attention to the election. ${ }^{29}$

Finally, the electoral administration was also overhauled to create at least an appearance of greater transparency. In spring 2016, the respected human rights ombudsman Ella Pamfilova replaced the buffoonish Vladimir Churov as CEC Chair. A further step in this direction - following a pilot project in the 2012 presidential election - was the installation of web-cams in 21,500 polling stations, which allowed remote monitoring of voting procedures in districts that covered about one-third of the Russian electorate. ${ }^{30}$ Having said this, many of the districts that did not have the cameras were the ones most frequently accused of electoral malpractice. $^{31}$

\section{The Actors}

Apart from the change of electoral system, the other noticeable innovation for 2016 was the ten-fold increase in the number of parties eligible to participate. After a decade in which the rules on party registration had become ever more onerous, the minimum number of members was reduced from 40,000 to just 500, which led to a mushrooming of new party organizations. By the qualifying date in 2016, 74 parties were eligible to seek nomination. ${ }^{32}$ Based on analysis of their levels of their public activities, however, no more than ten could be seen as serious organizations. ${ }^{33}$

Much was made of this higher level of pluralism, but there were reasons to doubt that it would make much difference. In regional elections held from 2013-15, newer parties generally struggled to register or clear electoral thresholds. ${ }^{34}$ Their sheer number also meant that they cancelled each other out, splitting votes and allowing the large parties to come

\footnotetext{
${ }^{29}$ Alexander Kynev, "How the Electoral Policy of the Russian State Predetermined the Results of the 2016 State Duma Elections”, Russian Politics 2, no. 2 (2017): 206-226.

${ }^{30}$ Central Electoral Commission, Vybory deputatov 2016. Elektoral'naya statistika: 9.

${ }^{31}$ For the 2017 regional elections, which took place in selected regions, Pamfilova announced that all polling stations would have web-cams, as well as the territorial electoral commissions (Viktor Khamraev, "Ella Pamfilova pokhvalila sebya pered vyborami”, Kommersant', 6 September 2017, https://www.kommersant.ru/doc/3403470 (accessed 8 September 2017).

${ }^{32}$ Ibid.: 6.

${ }^{33}$ Yury Korgunyuk, “Classification of Russian Parties”, Russian Politics 2, no. 3 (2017): 255-286.

${ }^{34}$ Grigorii V. Golosov, “Do Spoilers Make a Difference? Instrumental Manipulation of Political Parties in an Electoral Authoritarian Regime, The Case of Russia”, East European Politics 31, no. 2 (2015): 170-186.
} 
though the threshold unscathed. ${ }^{35}$ Most crucially, for State Duma elections, most parties were required to collect 200,000 valid signatures to register. No more than 7,000 could be from any individual region, and fewer than 5 percent could be declared invalid. ${ }^{36}$ In the meantime, 14 parties (the four State Duma parties and ten other minor parties with a presence in regional assemblies) were exempted from this requirement. These were ultimately the only ones that managed to register party lists; only four of the other 60 parties got as far as submitting signature lists to the CEC, and all of them were disqualified before registration. ${ }^{37}$

Despite the expansion of the cast, therefore, the actual list of dramatis personae for the 2016 State Duma election ultimately looked rather familiar. UR and the other three parliamentary parties were the favorites to retain their dominance of the State Duma. The other actors included the three that had participated in 2011 - the liberal Yabloko party; Patriots of Russia; and the Party of Growth ${ }^{38}$ - and several new parties. The liberal wing was augmented by former prime minister Mikhail Kas’yanov’s Party of People’s Freedom (better known by its Russian acronym, PARNAS). There were some obvious "spoilers" such as the confusingly-named Communist Party of Communists of Russia, and the Civic Force party, obviously modelled on the similarly-named (and almost as unsuccessful) Civic Platform. A number of parties resurrected old brands whose original guises had disbanded or reorganized, such as Motherland (Rodina) and the Russian Party of Pensioners and Justice, and the Greens. $^{39}$

But this novelty disguised an overall picture of stability. The leaders of the CPRF, LDPR and non-parliamentary Yabloko were heading their respective parties' lists for the seventh consecutive election, an unbroken run of 23 years. All four parliamentary parties had

\footnotetext{
${ }^{35}$ Kenneth Wilson, “How Increased Competition Can Strengthen Electoral Authoritarianism”, Problems of PostCommunism 63, no. 4 (2016): 199-209.

${ }^{36}$ Law on the Elections to the State Duma, 2016: Art. 44.3.

${ }^{37}$ Central Electoral Commission, Vybory deputatov 2016. Elektoral'naya statistika, 198-204. (Two parties - The Union of Labour (Soyuz Truda) and Party of the Great Fatherland - had too many invalid signatures. The other two - Will (Volya) and the Native Party (Rodnaya Partiya) - presented too few.)

${ }^{38}$ Despite a complete rebranding, renaming, and change of leadership, Boris Titov's Party of Growth was formally the same legal entity as the Right Cause party that had participated in 2007 and 2011, and could indirectly trace its roots back to the pro-business liberals of the early 2000s.

${ }^{39}$ For a more detailed overview of these parties’ programmes and policies, see Tat'yana S. Bolkhovitina, “Politicheskoe uchastie vneparlamentskikh partii v izbiratel’noi kampanii 2016: sravnitel’nyi rasklad”, Izvestiya Tul'skogo Gosudarsvtennogo Universiteta. Gumanitarnye nauki, no. 3 (2016): 3-9.
} 
the same lead candidates as in 2011. Allied to the continued background presence of a president who had been the main figure in Russian politics since the late 1990s, it was difficult to see much scope for fresh ideas in the campaign.

\section{Campaign}

The 2016 State Duma election campaign was perhaps the most low-key one in the post-Soviet era. Three weeks before polling day, only 8 percent of people named it as one of the news events that they remembered from the previous month. ${ }^{40}$ Apart from the timing of the election and the continuity of actors, the predictability of the result may also have played a role. Since 2011, the four main parties had held station in the regional assembly elections. ${ }^{41}$ The main intrigue - such as it was - was over the fight for second place in the party list election. Opinion polls in mid-2016 suggested that the LDPR, which had been 7.5 percent behind the CPRF in 2011, and consistently behind it in regional elections and earlier opinion polls, was narrowing the gap as the campaign went on. ${ }^{42}$

\section{Campaign Issues}

All the main parties took fairly conservative approaches to the campaign. Two political background factors played a role in this. First, Russia's foreign policy over the previous three years - the annexation of Crimea, intervention in Syria, and a ramping up of skeptical rhetoric about the West - met with widespread public approval. ${ }^{43}$ Whilst the approval rating of Russian foreign policy in general was highest amongst UR voters (75 percent), a majority of the other three parliamentary parties' electorates also supported it (57 percent of CPRF voters; 61 percent of LDPR voters; and 72 percent of AJR voters). ${ }^{44}$ Thus

\footnotetext{
${ }^{40}$ Levada-Center, “Zapomnivshiesya sobitiya”, 31 August 2016, https://www.levada.ru/2016/08/31/zapomnivshiesya-sobytiya-2/ (accessed 25 August 2017).

${ }^{41}$ Kynev, "How the Electoral Policy": 211

${ }^{42}$ Levada-Center, “Gotovnost’ golosovat' i predvybornye reitingi”, https://www.levada.ru/2016/09/01/gotovnost-golosovat-i-predvybornye-rejtingi/print/ (accessed 3 September 2017).

${ }^{43}$ In March 2016, 87 percent of Russians thought that Crimea should be part of Russia and 64 percent that it had “always been Russian” [Levada-Center, “Krym dva goda spustya: vnimanie otsenki, sanktsii”, 7 April 2016, https://www.levada.ru/2016/04/07/krym-dva-goda-spustya-vnimanie-otsenki-sanktsii/ (accessed 25 August 2017].

${ }^{44}$ Ian McAllister and Stephen White, 2016 Russian Duma Election Study, funded by the Australian National University, fieldwork by R-Research, 23 September-18 October 2016, N=2,003, question E29.
} 
there was little room for disagreement on this most crucial of policy issues among the major parties. Swimming against the tide, only some of the small extra-parliamentary parties, such as Yabloko and PARNAS, spoke out against the Crimean incorporation into Russia. ${ }^{45}$

The other background factor was the state of the economy. As figure 1 shows, the eight years of Putin's first two presidential terms were a period of unprecedented economic recovery after the collapse of the 1990s. Gross domestic product (GDP) had surpassed its 1990 output in real terms by 2007. Real wages rose by 11.6 percent per annum from 2000-05 and 7.6 percent from 2005-10. ${ }^{46}$ This strong economic growth translated into support for UR at the ballot box. ${ }^{47}$ The sharp recession of 2009-10 stopped this economic trajectory, and although weak growth returned from 2010-14, the picture at the time of the 2016 election was less rosy. As oil prices languished from 2014 onwards, the ruble collapsed, and capital flight and economic sanctions relating to the Crimean and Ukrainian situations began to bite. Formally, the economy dipped back into recession from the first quarter of 2015 to the end of 2016. By contrast with the tremendous growth of Putin’s first eight years in power, therefore, figure 1 shows that real GDP in rubles was only marginally higher by 2016 than it was in 2008 (and lower in dollar terms).

\footnotetext{
${ }^{45}$ Three of the four Duma parties explicitly mentioned the annexation of Crimea in their pre-election programmes in a positive light or as a priority for government funding. The CPRF did not mention it by name, but had voted in favour if its incorporation in the State Duma. By contrast, Yabloko's programme denounced it as illegal and called for Crimea's return to Ukraine [Yabloko, “Predvybornaya programma partii 'Yabloko': 'Uvazhenie k cheloveku’, 2016 god.”, 2016, http://www.yabloko.ru/program (accessed 7 September 2017).] ${ }^{46}$ Rosstat, Rossiya v tsifrakh. 2017. Kratkyi statisticheskii sbornik (Moscow: Rosstat. 2017), table 1.2: 37, http://www.gks.ru/wps/wcm/connect/rosstat_main/rosstat/ru/statistics/publications/catalog/doc_1135075100641 (accessed 10 August 2017).

${ }^{47}$ Ian McAllister and Stephen White, “'It's the Economy, Comrade!' Parties and Voters in the 2007 Russian Duma Election”, Europe-Asia Studies 60, no. 6 (2008): 931-957.
} 
Figure 1 Indexed real Russian GDP 1991-2016, rubles (1 January $1991=100$ )

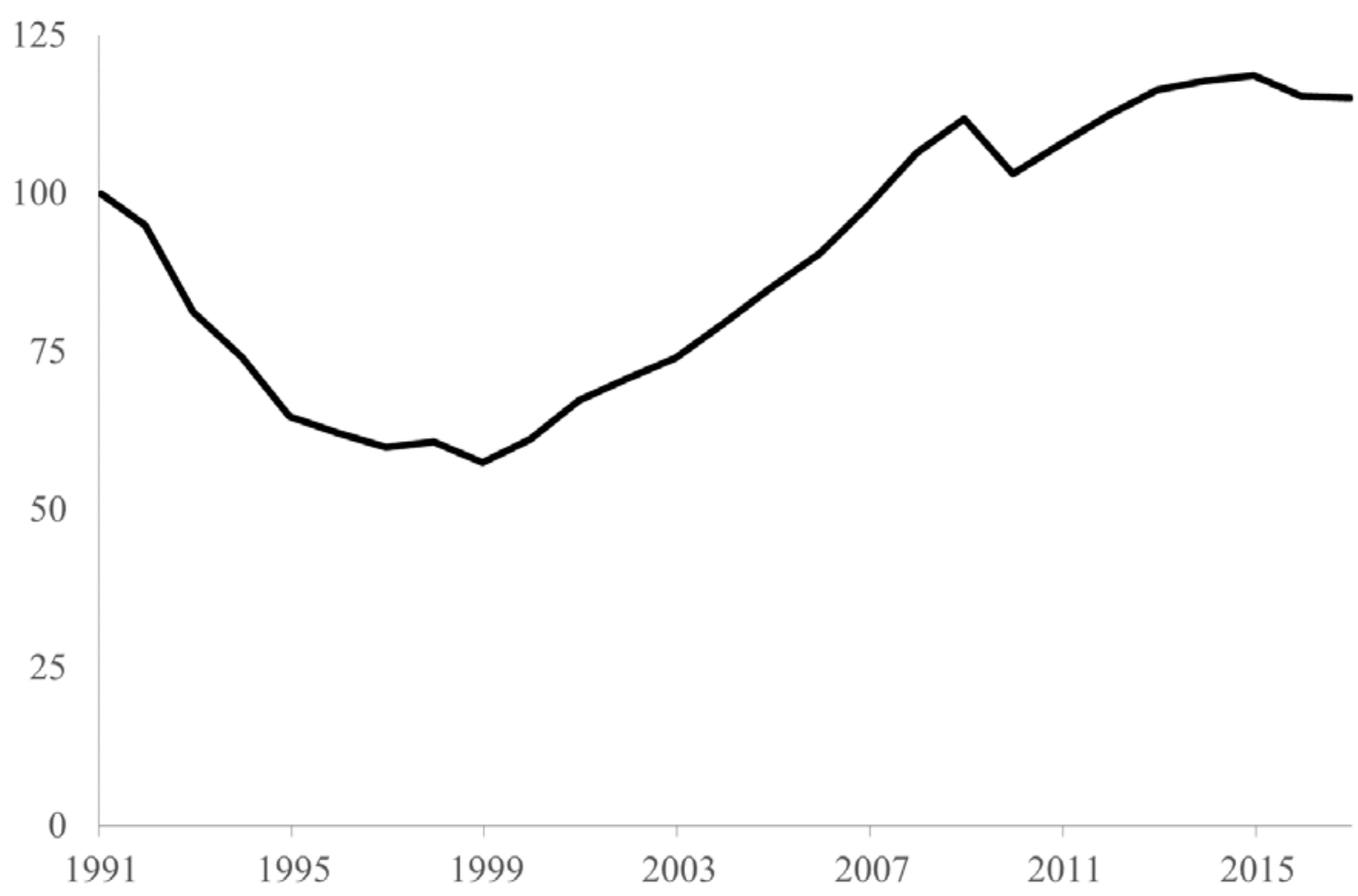

Source: Rosstat ${ }^{48}$

Under normal circumstances, as Hutcheson and McAllister note elsewhere in this volume, governments suffer in times of economic uncertainty. ${ }^{49}$ However, the macroeconomic recession did not necessarily become as an election-changing factor. State Duma elections are not about choosing a government, but rather, a legislature. Although UR was headed by the prime minister, the party as such was not directly responsible for day-to-day economic policy. Neither did the other main parties have economic policies that differed markedly from those that they had previously advocated - and had rejected - in previous elections.

\footnotetext{
${ }^{48}$ Source: Compiled from a combination of Rosstat, Sotsial'no-ekonomicheskie pokazateli Rossiiskoi Federatsii v 1991-2015gg. (prilozheniye k sborniku “Rossiiskii statisticheskii ezhegodnik. 2016”), 2016, table 10.1, http://www.gks.ru/bgd/regl/b16_13_p/Main.htm (accessed 10 August 2017); and Rosstat, "Valovoi vnutrennii produkt: godovye dannye (indeksy fizicheskogo ob”ema, v \% k predydushchemu godu)”, updated to 21 July 2017, http://www.gks.ru/free_doc/new_site/vvp/vvp-god/tab3.htm (accessed 10 August 2017).

${ }^{49}$ Derek S. Hutcheson and Ian McAllister, “Explaining Party Support in the 2016 Russian State Duma Election”, Russian Politics 2, no. 4 (2017): 454-481..
} 
Perhaps most crucially, the economic crisis and the more assertive policy became linked in voters' minds, in a manner that actually allowed the regime to capitalize on the sense of economic besiegement. The devaluation of the ruble and the low international price of oil were to some extent exogenous factors. Russians were also defiant in the face of international sanctions. In August 2016, 70 percent thought that the country should pursue its own course, despite the sanctions. Russia’s own import ban on many Western food products was supported by many, despite the obvious negative effect on the prices, quality and variety of daily groceries available to them. More people (33 percent) thought that the West would suffer than Russia (15 percent) from this ban. The proportion of people (58 percent) who thought that Russia's countersanctions had made other countries respect it more was twice as high as the number who thought they were having a negative effect on the lives of the Russian people (23 percent). ${ }^{50}$ In other words, the economic crisis was seen by many as a price worth paying for the reassertion of Russian pride on the international stage, and it reinforced the authorities’ narrative about Western threats to their wellbeing.

\section{Party campaign strategies}

Given these two factors, the election campaign gave little scope for controversy, and the campaign was rather low-key. The smaller parties generally campaigned only in a few regions, while the larger parliamentary parties were more active nationwide. UR's total campaign budget - of just under 2.4 billion rubles - dwarfed that of any other party. The three other parliamentary parties fought their campaign on between 300 and 800 million rubles. Of the ten non-parliamentary parties, only Yabloko and the Party of Growth had comparable budgets. Four parties had less than 5 million rubles in their accounts; and four others, between 15 and 35 million. ${ }^{51}$ Clearly, a level playing field did not emerge from the additional number of players.

Despite these sums, the campaigns failed to ignite much interest. With prime minister Dmitrii Medvedev at the helm, it was difficult for UR to pose as a dynamic new force in the middle of a recession. Paradoxically, however, it could depict itself as itself as a source of stability in times of (putatively externally-imposed) uncertainty. Medvedev utilized opportunities such as the start of the school year and the harvest season to be depicted smiling

\footnotetext{
${ }^{50}$ Levada-Center, "Bolshinstvo grazhdan ne svyazyvayut krizis s sanktsiyami”, https://www.levada.ru/2016/08/18/bolshinstvo-grazhdan-ne-svyazyvayut-krizis-s-sanktsiyami/print/ (accessed 3 September 2017).

${ }^{51}$ Central Electoral Commission, Vybory deputatov 2016. Elektoral'naya statistika: 266-267.
} 
next to happy children, ripe vegetables and sunny fields, and meeting meet doctors, teachers and farmers. A second strand to the UR campaign was to emphasize its concrete microachievements at the regional level, such as the opening of new sports complexes and kindergartens. Later in the campaign, as its poll numbers flagged, it sought to benefit from the president's reflected popularity. ${ }^{52}$ Medvedev and Putin went on a highly-filmed dual executive fishing trip together. A few days later, in more formal attire, they inspected the construction of the Crimean (Kerch Strait) Bridge - a photo opportunity designed to remind voters of their efforts to "connect the peninsula to the rest of the country", as the prime minister poetically described it. ${ }^{53}$

The CPRF had managed to gather votes in 2011 as the repository of within-system protest, but its compliance with many of the Kremlin's most prominent policy initiatives over the previous five years meant that it was increasingly associated with the parliamentary "cartel" rather than regarded as a true force of opposition. ${ }^{54}$ Its campaign repeated many of the tropes that it had espoused in all previous campaigns since 1993, but it had little new to add to them. AJR's campaign was similarly low-key, and its printed advertising - such as election posters - looked remarkably similar to the CPRF's in format and substance, apart from being bit more yellow.

On this occasion, the role of within-system opponent was played best by the LDPR ironically, given that its firebrand rhetoric has long masked a high degree of pro-Kremlin voting in the State Duma. It trained its focus on the failures of the government on domestic issues, given that its previous nationalistic pitch was now mainstream public policy. Zhirinovsky represented the party in the television debates personally (many of the other party leaders, most notably Medvedev, sent proxies), and the LDPR's punchy television advertisements focused on issues that tapped into voters everyday concerns, such as rising grocery prices, housing issues, education, healthcare, transport, and debt collection. ${ }^{55}$

\footnotetext{
${ }^{52}$ Petr Kozlov and Elena Mukhametshina, “Pora zvat’ Putina”, Vedomosti, 1 September 2016, https://www.vedomosti.ru/politics/articles/2016/09/01/655261-reiting-partii-vlasti (accessed 3 September 2017).

${ }^{53}$ Dmitrii Medvedev, Twitter post, 15 September 2016, https://twitter.com/MedvedevRussia/status/776497244853923841 (accessed 25 August 2017).

${ }^{54}$ Derek S. Hutcheson, "Party Cartels beyond Western Europe: Evidence from Russia”, Party Politics 19, no. 6 (2013): 907-924.

${ }^{55}$ Liberal Democratic Party of Russia (LDPR), “Predvybornoe Video”, LDPR website, http://ldpr.ru/events/Pre_election_video/?page=1 (accessed 28 June 2017).
} 
As table 1 shows, the LDPR's more lively campaign was picked up on by voters. It was perceived as the most active party, and the best performer in televised debates. More than two-fifths of respondents cited Zhirinovsky (unprompted) as a party leader they had seen in the debates, the highest of the main parties. Together with UR, it was also perceived to have had the most memorable election advertisements. What is striking about the figures in table 1 , however, is how low they were in general, even for the winning party. In 2007, 51 percent of respondents thought that UR had been particularly active in the last week of the campaign; in 2016, the figure was less than one in five. Similarly, 45 percent remembered its advertisements in 2007 and 25 percent in 2011; just 18 percent remembered seeing one in 2016.

Table 1: Evaluations of 2016 election campaigning activity (percentage respondents)

\begin{tabular}{lrrrr}
\hline & Best in debates & Memorable adverts & Most active in last week & Memorable leaders* \\
\hline UR & 33 & 18 & 18 & 12 \\
CPRF & 22 & 9 & 6 & 24 \\
LDPR & 14 & 10 & 44 \\
AJR & 39 & 6 & 4 & 14 \\
\hline SJR
\end{tabular}

Source: Levada-Center ${ }^{56}$

\section{Single member districts}

Given the strong media focus on the party list part of the vote, it was easy to forget that half of the State Duma deputies were elected as individual constituency representatives. In total, 2,030 candidates were registered (out of 2,549 that were nominated) in the SMDs - an average of 9 per seat. This was slightly higher than in 2003, the last time SMD candidates were elected (1,895 candidates), and slightly lower than $1999(2,226) .{ }^{57}$ The dynamics of the campaigns in each region depended to some extent on local personalities and characteristics, but the main factor predicting success was party affiliation.

Until 2003, in the context of a weak and fragmented party system, the SMDs frequently gave non-party candidates a channel into national politics. Some 67 deputies were

\footnotetext{
${ }^{56}$ Levada-Center, “Vlyanie SMI na golosvanie”, 5 October 2016, https://www.levada.ru/2016/10/05/vliyaniesmi-na-golosovanie/print/ (accessed 25 August 2017); Levada-Center, "Predvybornaya agitatsiya i zloupotrebleniya”, 22 September 2016, https://www.levada.ru/2016/09/22/predvybornaya-agitatsiya-izloupotrebleniya/print/ (accessed 25 August 2017).

${ }^{57}$ Central Electoral Commission, Vybory deputatov Gosudarstvennoi Dumy Federal'nogo Sobraniya Rossiiskoi Federatsii. 2003. Elektoral'naya statistika (Moscow: CEC/Ves' Mir, 2004): 193.
} 
elected in 2003 without any party affiliations (though many of these people were later coopted into the UR faction in the State Duma) - and the number was higher in previous contests. ${ }^{58}$ Indeed, often candidates engaged in a calculus of whether to run as a partyaffiliated candidate or not, finding that local patronage networks were of more use than national party brands. ${ }^{59}$ The SMDs also gave smaller parties a chance to win seats: by concentrating their resources on achieving victory in a small geographical area, they were able to win individual seats rather than having to attain 5 percent of the vote nationwide.

Both these outcomes were very rare in 2016. The SMD part of the election exhibited the normal first-past-the-post tendency to reward the winning party disproportionately. Nor was there a profusion of independent candidates using their own resources to campaign. Most such individuals would in any case have been co-opted into the system rather than risking opposing it. Moreover, the requirement to collect nomination signatures from 3 percent of the registered voters in the constituency meant that, once attrition and refusal rates were factored in, campaigners would have had to visit virtually every household just to gather the requisite number of signatures to get on the ballot. ${ }^{60}$ Only 19 self-nominated independents were registered across the whole country, and only five of them gathered more votes on election day that they had collected signatures to register. ${ }^{61}$ The only self-nominated candidate to win election - Vladislav Resnik - was something of an exceptional case in the first place. ${ }^{62}$

In almost every seat there was a clear favorite. In the 206 seats where the party put up a contender, the UR candidate was considered highly likely to win. In an indication of the “cartelization” of the Russian party system, UR omitted to nominate candidates in 18 seats, as

\footnotetext{
${ }^{58}$ Central Electoral Commission, Vybory Deputatov 2003: 192.

${ }^{59}$ Regina Smyth, Candidate Strategies and Electoral Competition in the Russian Federation: Democracy Without Foundation (New York: Cambridge University Press): 128.

${ }^{60}$ Kynev, "How the Electoral Policy”: 216.

${ }^{61}$ Central Electoral Commission, Vybory deputatov 2016. Elektoral'naya statistika: 6/343.

${ }^{62}$ Reznik was a sitting UR deputy who had been omitted from the official UR list of candidates (an international arrest warrant had been issued for him in March 2016 concerning links to organized crime in Spain, rescinded in May 2016). He stood as a self-nominated candidate in constituency 1 (Adygeya), but UR did not oppose his candidature in a region with which he had no obvious previous connection. He rejoined the UR faction after the election [Anton Smertin, “Avtoritetnyi edinoross Vladislav Reznik poidet v Gosdumu ot Adygei”, RBK, 1 July 2017, http://kuban.rbc.ru/krasnodar/01/07/2016/57768b959a79475c749309f0 (accessed 28 August 2017);
} Bradley Jardine, “Meet Vladislav Reznik, Russia’s Only ‘Independent’ Deputy”, The Moscow Times, 20 September 2016, https://themoscowtimes.com/articles/vladislav-reznik-55395 (accessed 28 August 2017)]. 
part of what appeared to be a strategy to give several prominent candidates from the parliamentary opposition, such as committee chairs from the outgoing Duma, a clear run. In such seats, these people became the de facto establishment candidates. ${ }^{63}$ One exception was the north Moscow Medvedkov constituency (district 200), where the UR candidate was forced to withdraw halfway through the campaign. ${ }^{64}$ This made it the most unpredictable seat in the country. (It was ultimately won by the CPRF candidate, Denis Parfenov, against stiff opposition from the LDPR, Yabloko and Green Party candidates.)

\section{Result}

\section{Voting patterns}

The overall result of the 2016 State Duma was an overwhelming victory for United Russia. As table 2 shows, it won a supermajority of 343 out of 450 seats in the State Duma, and garnered 28.5 million votes. This represented a 54.2 percent share of the vote, a relative increase on 2011. UR's vote total was four times higher than either the CPRF and LDPR attained, and more than all the other parties' combined.

63 “U odnomandatnikov i bez ‘Edinoi Rossii’ nashlis’ protivniki”, Kommersant’, 15 August 2016: 3, http://www.kommersant.ru/doc/3064084?utm_source=kommersant\&utm_medium=strana\&utm_campaign=four (accessed 4 September 2017).

${ }^{64}$ Tat'yana Barsukova, the Deputy Head of the Department of Labour and Social Protection of the Population of Moscow, signed off on a children's summer camp trip to Karelia in which 14 children tragically drowned in June 2016. Although she was not charged with negligence personally, her presence on the ballot was thought likely to be used as an election issue by UR's opponents [Mikhail Rubim and Elizaveta Antonova, “Otpravivshaya detei v Kareliyu chinovnitsa snyalas’ s vyborov v Gosdumu”, RBK, 20 July 2016, http://www.rbc.ru/politics/20/07/2016/578f8f399a7947ee67293085 (accessed 28 August 2017)]. 
Table 2 Result, Election to the State Duma (VII Convocation), 18 September 2016

\begin{tabular}{|c|c|c|c|c|c|}
\hline Party & Votes & $\%$ & $\begin{array}{r}\text { PR } \\
\text { Seats }\end{array}$ & $\begin{array}{l}\text { SMD } \\
\text { Seats }\end{array}$ & Total \\
\hline United Russia (UR) & $28,527,828$ & $54.20 \%$ & 140 & 203 & 343 \\
\hline Communist Party of the Russian Federation (CPRF) & $7,019,752$ & $13.34 \%$ & 36 & 6 & 42 \\
\hline Liberal Democratic Party of Russia (LDPR) & $6,917,063$ & $13.14 \%$ & 34 & 5 & 39 \\
\hline A Just Russia (AJR) & $3,275,053$ & $6.22 \%$ & 16 & 7 & 23 \\
\hline \multicolumn{6}{|l|}{ 5\% threshold } \\
\hline Communist Party of Russian Communists & $1,192,595$ & $2.27 \%$ & & & \\
\hline Yabloko & $1,051,335$ & $1.99 \%$ & & & \\
\hline Russian Party of Pensioners for Justice & 910,848 & $1.73 \%$ & & & \\
\hline Motherland Party & 792,226 & $1.51 \%$ & & 1 & 1 \\
\hline Party of Growth & 679,030 & $1.29 \%$ & & & \\
\hline Greens & 399,429 & $0.76 \%$ & & & \\
\hline Party of People's Freedom (PARNAS) & 384,675 & $0.73 \%$ & & & \\
\hline Patriots of Russia & 310,015 & $0.59 \%$ & & & \\
\hline Civic Platform & 115,433 & $0.22 \%$ & & 1 & 1 \\
\hline Civil Force & 73,971 & $0.14 \%$ & & & \\
\hline Independent (V. Reznik) & & & & 1 & 1 \\
\hline
\end{tabular}

Its victory in the party list part of the contest was augmented by an almost clean sweep of the SMD seats, winning 203 of the 206 seats it contested. In the small number of SMD seats in which it stood aside as part of its informal pact with the parliamentary opposition, the non-UR pre-election favorites generally won. Only in three constituencies was a UR candidate directly defeated at the polls (in all three cases, by a CPRF candidate).

However, UR's victory was based on a relatively narrow foundation. The general lack of engagement in the election campaign translated into a sharp drop in electoral turnout, which fell compared with 2011 in 79 regions and rose in only four. ${ }^{66}$ Overall, just 47.9 percent of the electorate participated. This was a fall of 12.3 percentage points compared with 2011, and represented the first time in post-Soviet history that more people had stayed at home than gone to the polls. Although was no legal minimum turnout, UR's victory was clearly based on an underwhelming endorsement of the electoral process itself.

Table 3 splits the 225 constituencies into four quartiles (ordered by turnout as a percentage of the registered electorate in each seat, regardless the size of the constituency). Notable in the first instance is how low the threshold for top quartile was - 52.1 percent -

\footnotetext{
${ }^{65}$ Central Electoral Commission, Vybory deputatov 2016. Elektoral'naya statistika: 340-3.

${ }^{66}$ Ibid.: 136-38.
} 
meaning that in almost three-quarters of electoral districts, only a minority or a very small majority of people voted. There was also - as has been the case in most national elections since the turn of the century - a significant skew to the distribution of turnout, with a handful of regions (many of them national republics) reporting exceptionally high levels of turnout. ${ }^{67}$ To set this into perspective, table 3 shows that the highest-turnout constituencies cast more than a third of the votes, despite constituting less than a quarter of the electorate.

Table 3 Accumulated votes by party, by turnout quartile

\begin{tabular}{lrrrrr}
\hline & $\mathbf{1}^{\text {st }}$ quartile & $\mathbf{2}^{\text {nd }}$ quartile & $\mathbf{3}^{\text {rd }}$ quartile & $\mathbf{4}^{\text {th }}$ quartile & Totals \\
\hline Turnout range & $30.8 \%-37.9 \%$ & $40.0 \%-42.7 \%$ & $42.8 \%-52.0 \%$ & $52.1 \%-94.9 \%$ & \\
Electorate & $28,088,401$ & $28,153,422$ & $26,948,509$ & $26,870,868$ & $110,061,200$ \\
& & & & & \\
Turnout (N) & $9,877,256$ & $11,290,654$ & $12,463,656$ & $19,069,426$ & $52,700,992$ \\
Turnout (\%) & $35.2 \%$ & $40.1 \%$ & $46.2 \%$ & $71.0 \%$ & $47.9 \%$ \\
& & & & & \\
UR votes & $3,909,943$ & $4,856,625$ & $6,412,822$ & $13,348,438$ & $28,527,828$ \\
CPRF+LDPR+AJR & $3,770,728$ & $4,633,037$ & $4,388,409$ & $4,419,694$ & $17,211,868$ \\
Other (10) parties & $1,923,014$ & $1,501,639$ & $1,382,107$ & $1,102,797$ & $5,909,557$ \\
Total votes & $9,603,685$ & $10,991,301$ & $12,183,338$ & $18,870,929$ & $51,649,253$ \\
\hline
\end{tabular}

Note: Turnout is calculated by the CEC as the number of people "taking part in voting”, which is slightly higher than the total number of votes cast (which is the denominator for calculating percentages of the vote).

Source: Central Electoral Commission ${ }^{68}$

Differential turnout - combined with its success in the SMD seats - was the main mechanical explanation for UR's substantial victory. Elsewhere in this issue of Russian

\footnotetext{
${ }^{67}$ Only in 62 out of 225 constituencies did more people vote than stayed at home (turnout 50 percent or above), but the range of the top quartile was approximately twice as large (52.1 percent to 94.9 percent) as that of the bottom three quartiles combined (30.8 percent to 52.1 percent).

${ }^{68}$ Central Electoral Commission, “Vybory deputatov Gosudarstvennoi Dumy Federal’nogo Sobraniya Rossiiskoi Federatsii sed'mogo sozyva: Svodnaya tablitsa rezul'tatov vyborov po federal'nomu izbiratel'nomu okrugu”, 23 September 2016, http://www.vybory.izbirkom.ru/region/region/izbirkom?action=show\&root=1\&tvd=100100067795854\&vrn=10 0100067795849\&region=0\&global=1\&sub_region=0\&prver $=0 \&$ pronetvd=0\&vibid $=100100067795854 \&$ type $=2$ $\underline{33}$ (accessed 28 June 2017).
} 
Politics, Ian McAllister and Stephen White delve deeper into the factors that lay behind it, ${ }^{69}$ but in this article several observations can be made about its effect.

Overall, UR lost 3.85 million votes compared with 2011, but its share increased due to the lower number of participants and the higher drop-off rates for other parties. Although it slightly increased its vote share in some of the low-turnout provinces compared with 2011, its overall performance in these was much poorer (at least by its own standards) than in the highturnout districts. ${ }^{70}$ In the bottom turnout quartile of constituencies it won only two out of five votes; the other three went to other parties (although UR was the largest single party in each case). Because fewer votes were cast in the first place in these regions, however, the opposition's extra support was swamped by UR's stronger performances in high-turnout regions. As table 3 shows, UR accumulated almost half its nationwide support (13.3 million votes) from the 56 constituencies with the highest turnout alone. This was almost twice as many votes as any other single party attained nationwide.

Figure 2 Turnout and UR vote percentages, 2016 State Duma Election

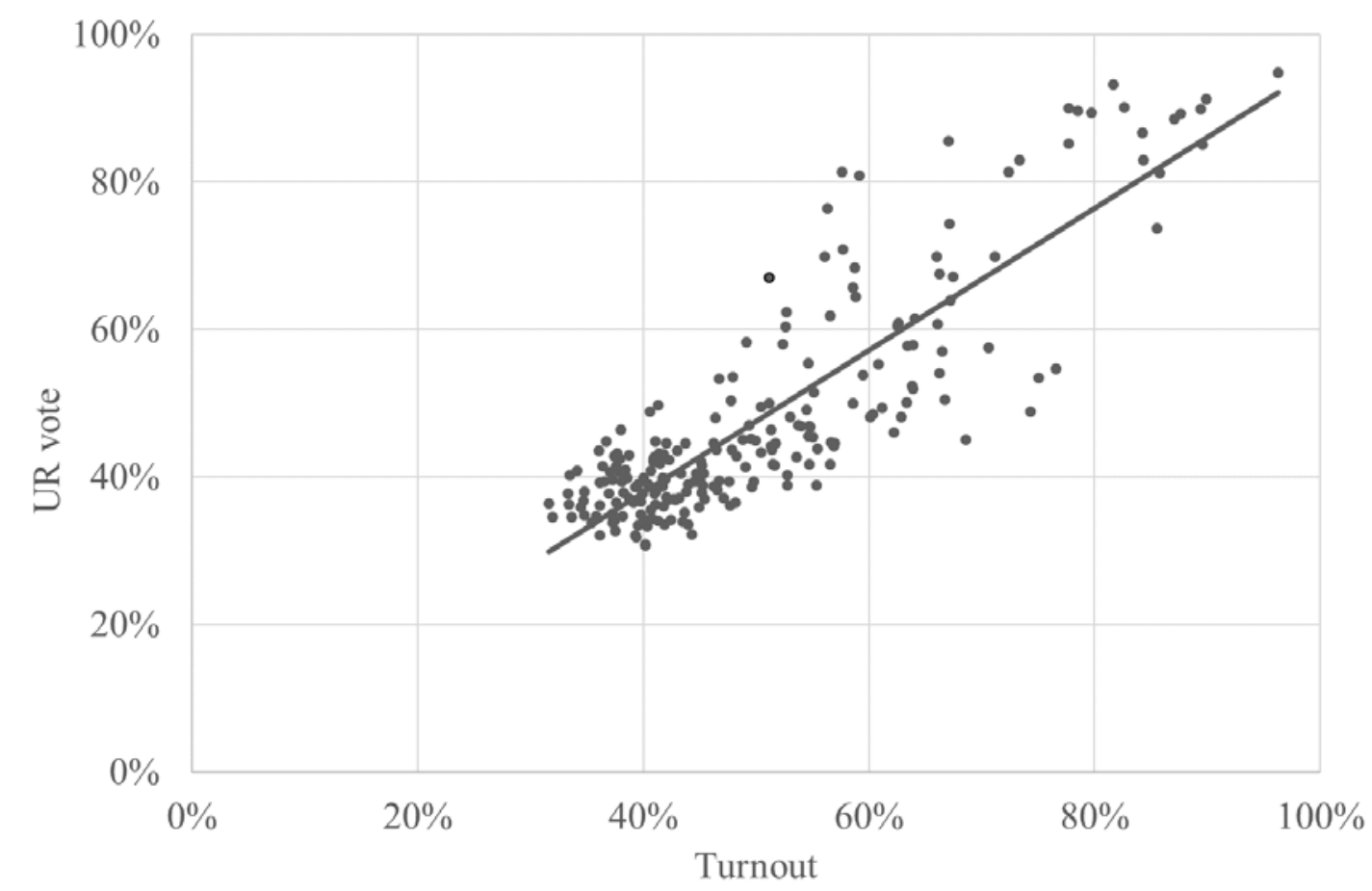

\footnotetext{
${ }^{69}$ Ian McAllister and Stephen White, “Demobilizing Voters: Election Turnout in the 2016 Russian Election”, Russian Politics 2, no. 4 (2017): 411-433.

${ }^{70}$ In the four quartiles (arranged by turnout) in table 3, its support amongst the lowest quartile was 39.7 percent, and 43.1 percent, 51.5 percent and 70.0 percent in quartiles 2, 3 and 4 respectively.
} 
Plot shows the relative percentage of the UR vote by turnout level in the party list vote, across the 225 constituencies (electoral districts). Each data point represents one electoral district.

Source: Central Electoral Commission ${ }^{71}$

The connection between turnout and UR votes is confirmed by figure 2, which shows relative UR support levels amongst those that voted, plotted against turnout, across the 225 constituencies. There is a Pearson coefficient of 0.86 between the two. The manner of UR's victory become much more apparent when looking at the number of votes rather than their relative shares. Collectively, the other parties' vote numbers were relatively similar across the four quartiles. What made the difference was that, in high turnout regions, almost all additional votes went to UR and not to the other 13 parties.

This pattern has been well established for several election cycles. What used to be a "red belt" of pro-Communist regions in the 1990s has in the 2000s been UR's stronghold. UR support was also found, in previous elections, to be related to the presence of ethnic minorities in particular districts. ${ }^{72}$ In approximately half the ethnic regions (most notably those of the North Caucasus and Tatarstan) it has routinely recorded exceptionally high levels of support. Given that this coincided with the reorientation of these regions' political machines in the early 2000s, it appears that at least part of its success derives from the exceptional mobilization efforts made by a handful of regional elites. After 2011's wobble, control was firmly re-established in 2016.

\section{Electoral integrity}

With the spectacular success of UR for the fourth election running, enhanced by a handful of regions with exceptionally good results for UR, the question that naturally arises is this: was the electoral process clear and transparent, and did it actually reflects the voters' will? Voters themselves were somewhat skeptical about this after the election. Despite the greater transparency with which the election was organized centrally, only 44 percent regarded the

\footnotetext{
${ }^{71}$ Source: Central Electoral Commission, “Vybory Deputatov (svodnaya tablitsa) 2016”.

${ }^{72}$ Allison C. White, "Electoral Fraud and Electoral Geography: United Russia Strongholds in the 2007 and 2011 Russian Parliamentary Elections”, Europe-Asia Studies 68, no. 7 (2016): 1127-1178.
} 
counting process as “fair” - lower than in 2011's figure of 52 percent and a significant step below the average of 63 percent from 1999-2007. ${ }^{73}$

The view of international observers was also ambiguous. Whilst the Commonwealth of Independent States' observation mission concluded that the election was “consistent with the principles of holding democratic elections" and "open and competitive”, ${ }^{74}$ the more broadbased Organization for Security and Cooperation in Europe (OSCE) report gave a mixed assessment. It commended the efficiency of the electoral process, but voiced concern about overarching "restrictions to fundamental freedoms and political rights, firmly controlled media and a tightening grip on civil society". ${ }^{75}$ In particular, it drew attention to the use of local administrative resources to restrict access to campaign premises and campaigning opportunities, and the domination of the media coverage by UR, the president and the government. Nonetheless, it was satisfied that the voting procedures themselves were relatively well-administered, even if the counting processes contained many (technical) violations of the election law.

Domestic observation was rendered more difficult than before because of the requirement that observers be nominated to particular polling stations in advance. The electoral observation organization Golos circumvented some of these restrictions and monitored the campaigns, advertising, financing and voting of the election. It concluded "the level of violations was lower than in 2011" but that the election was "far from being able to be genuinely called free and fair". 76

Another observation of the OSCE mission was that the CEC had administered the election in a generally transparent manner, but that the performance of lower-level commissions was

\footnotetext{
${ }^{73}$ Ian McAllister and Stephen White, 2016 Russian Duma Election Study, C4. The trends are taken from similar surveys conducted by the same authors (and collaborators) from 2000 to 2012. See Hutcheson and McAllister, “Explaining Party Support”, for full details.

${ }^{74}$ CIS Election Observation Mission (2016), “Zayavleniye Missii nablyudatelei ot SNG po rezul'tatam nablyudeniya za podgotovkoi i provedeniyem vyborov deputatov Gosudarstvennoi Dumy Federal'nogo Sobraniya Rossiiskoi Federatsii sed’mogo sozyva”, http://www.e-cis.info/page.php?id=25676 (accessed 3 September 2017).

${ }^{75}$ OSCE/ODHIR, Russian Federation. State Duma Elections. 18 September 2016. OSCE/ODIHR Elections Observation Mission. Final Report (Warsaw: ODIHR, 2016): 1, http://www.osce.org/odihr/elections/russia/290861 (accessed 28 June 2017).

${ }^{76}$ Golos, “Predvaritel’noe zayavlenie po rezul’tatami nablyudeniya za vyborami 18 sentyabrya 2016 g.”, 19 September 2016, https://www.golosinfo.org/ru/articles/117564 (accessed 31 August 2017).
} 
more patchy. Much more effort was made in 2016 than in 2011 to present a picture of electoral integrity from the top down. Whereas Vladimir Churov had dismissed fears of interference with the GAS-Vybory computer system in 2011 as "the perverse fantasies of little people”, ${ }^{77}$ Ella Pamfilova gave frequent updates on the attempts of the Commission to ensure that the election was honestly administered, and she engaged in public discussions with local electoral commission officials to implore them to investigate allegations of malfeasance. The aforementioned video web-cams caught at least one example of ballot stuffing red-handed. ${ }^{78}$ These covered areas that contained about a third of the Russian electorate - but left some of the most questionable regions unobserved.

The Commission's own complaints procedures saw significantly more disputes about the electoral process in 2016 than 2011 - in part because it was encouraging greater reporting and transparency. At 8 percent, however, the resolution rate was slightly lower. The largest proportion of the 2,693 complaints submitted (and the largest group of those upheld) concerned the informational aspects of the election, mainly violations by candidates and parties about the rules, forms and periods of campaigning. A quarter of the appeals concerned election day mistakes by electoral commissions. Only a handful of the complaints that concerned falsification (16 of 173) were upheld, ${ }^{79}$ but they had significant consequences, including the annulment of nine polling station results. ${ }^{80}$

Fraud of an altogether different magnitude was alleged by analysis of the turnout patterns. In recent years, there has been increasing use of statistical modelling to detect possible “fingerprints of fraud”. A “toolbox” of forensic tests, applied to various post-Soviet elections, have pointed to certain regions have routinely have anomalous results compared to the

\footnotetext{
77 Svetlana Sukhova, "Vladimir Churov: 'Plokhoye delo okhaivat' ne budut, znachit, vybory byli khorosho organizovany i proshli na vysokom urovne’”, Itogi, 6 December 2011, http://www.itogi.ru/polittema/2011/49/172355html, accessed 28 June 2017.

${ }^{78}$ Four members of the Rostov-on-Don polling station 1958 electoral commission pleaded guilty in May 2017 to attempting to add 764 ballot papers to the urn. The chair was fined 350,000 rubles and the other members, 300,000 rubles [Denis Shadrin, ““Golos’: Vlast’ prodolzhaet nedootsenivat’ beznakazannost' prestuplenii na vyborakh”, 30 August 2017, https://www.golosinfo.org/ru/articles/142143 (accessed 31 August 2017)].

${ }^{79}$ In part, the low resolution rate is due not only to a lack of evidence, but to multiple reports of the same incidents being lodged and counted separately (Central Electoral Commission, Vybory deputatov 2016. Elektoral'naya statistika: 490).

${ }^{80}$ RIA-Novosti, “Itogi vyborov v Gosdumu otmeneny na devyati uchastkakh”, 21 September 2016, https://ria.ru/election2016/20160921/1477527343.html (accessed 4 September 2017).
} 
others. ${ }^{81}$ In 2011 and 2016 the most prominent critic of the voting figures was the well-known physicist Sergei Shpil'kin. Based on statistical analysis of the distribution curves of turnout, he alleged that it (and the vote for UR) had been artificially inflated in several regions, including Tatarstan, Bashkortostan, the republics of the North Caucasus (apart from Adygeya) and several provinces. In consequence, he suggested, the real turnout was closer to 36.5 percent (instead of 47.9 percent) and UR had won no more than 40 percent of the vote (compared with its officially-attributed 54.2 percent). ${ }^{82}$

The figures in table 3 did indicate that UR's support was were exceptionally high in regions with high turnout. Such was the margin of UR's victory, however, that there is little doubt of the fact that it was in any event the party with the most votes, even on Shpil'kin's assessment. It should also be noted that these allegations are based on statistical extrapolation of results, rather than concrete allegations of fraud backed up with "red-handed" evidence. At one level, it strains credulity to suggest that fraud could have been so extensive, with so little actual evidence of its occurrence on the ground. To achieve it, electoral commissions would have to disguise large-scale alteration of the results, under the gaze of observation, and with retrofitting required to make the results add up at the polling station level - an enormous logistical task. Nonetheless, it is also worth noting that there have been several elections in a row in which the voters in a handful of regions of Russia that routinely behaved exceptionally compared to the rest, at least according to the published electoral results. It is a matter taken up elsewhere in this issue by Max Bader's detailed analysis of the dynamics of electoral commission activity in polling stations where such results occur. ${ }^{83}$

\section{The articles in this volume}

A more overarching question over Russian elections is about the extent to which the system itself allows for free and fair elections. It has been fashionable in recent years to put Russia

\footnotetext{
${ }^{81}$ Mikhail Myagkov, Peter C. Ordeshook and Dimitri Shakov, The Forensics of Election Fraud: Russia and Ukraine (Oxford: Oxford University Press, 2009).

${ }^{82}$ Anna Baidakova, “Realno ‘Edinuyu Rossiyu’ podderzhali 15\% izbiratelei: Intervyu fizika Sergeya Shpil’kina”, Novaya Gazeta, 21 September 2016, http://www.novayagazeta.ru/politics/74630.html?print=1, accessed 30 August 2017. Shpil'kin has published his estimates of statistical anomaly for all federal elections since 1996: http://www.epde.org/tl_files/EPDE/EPDE\%20PRESS\%20RELEASES/s_shpilkin_osce_memo.pdf (accessed 5 September 2017).

${ }^{83}$ Max Bader, “The Role of Precinct Commissions in Electoral Manipulation in Russia: Does Party Affiliation Matter?”, Russian Politics 2, no. 4 (2017): 434-453.
} 
into the category of "electoral authoritarian" regimes - clearly, more of the hegemonic than the competitive kind. ${ }^{84}$ Some go further towards describing it as fully authoritarian, ${ }^{85}$ while others argue that - notwithstanding the institutional engineering that has created the executive dominance and an ossified party system - there is still merit in examining Russian elections in a comparative context. ${ }^{86}$

All four remaining articles in this collection touch upon this central question, to a greater or lesser extent. The first major debate is about the extent to which electoral turnout anomalies were the result of manipulation or of voter behavior. McAllister and White examine the bases of differential turnout in the 2016 election and conclude that there were clear societal triggers for this, most notably variable levels of support for the incumbent president and the authorities, and the level of voters' trust in the electoral process. Nonetheless, they also show that it clearly advantaged UR. ${ }^{87}$ Max Bader, meanwhile, delves deeper into the mechanisms of control by the authorities over the electoral process, zeroing in on the composition of electoral commissions. ${ }^{88}$ By comparing micro-level analysis of the composition of every polling station in Russia with the results reported by them, he concludes that there was a small but statistically significant positive relationship between the presence of UR officials in positions of authority on polling station electoral commissions, and the extent to which the voters (or at least the results protocols) in the same polling districts supported UR. This finding calls into question the extent to which the lower-level administration of the election was impartial - whilst backing up the assertions of the higher-level ones that it should be.

\footnotetext{
${ }^{84}$ Grigorii V. Golosov, “The Regional Roots of Electoral Authoritarianism in Russia”, Europe-Asia Studies 63, no. 4 (2011): 623-639; Cameron Ross, “Regional Elections and Electoral Authoritarianism in Russia”, EuropeAsia Studies 63, no. 4 (2011): 641-661; Graeme Gill, "Russia and the Vulnerability of Electoral Authoritarianism?”, Slavic Review 75, no. 2 (2016): 354-373; Graeme J. Gill, “The Decline of a Dominant Party and the Destabilization of Electoral Authoritarianism?”, Post-Soviet Affairs 28, no. 4 (2012): 449-471; Wilson, “How Increased Competition Can Strengthen Electoral Authoritarianism”.

${ }^{85}$ William Zimmerman, Ruling Russia: Authoritarianism from the Revolution to Putin (Princeton: Princeton University Press, 2014); Vladimir Gel'man, Authoritarian Russia: Analyzing Post-Soviet Regime Change (Pittsburgh, PA: University of Pittsburgh Press, 2015); Grigorii V. Golosov, “Authoritarian Learning in the Development of Russia’s Electoral System”, Russian Politics 2, no. 2 (2017): 182-205.

${ }^{86}$ Derek S. Hutcheson, Parliamentary Elections in Russia: A Quarter-Century of Multiparty Politics (Oxford/London: British Academy/Oxford University Press, 2018 forthcoming).

${ }^{87}$ McAllister and White, “Demobilizing Voters”.

${ }^{88}$ Bader, “The Role of Precinct Commissions”.
} 
The article by Hutcheson and McAllister takes a slightly different approach. Whilst acknowledging the wider academic consensus that puts Russia into the category of an “electoral authoritarian” regime, they argue that we should not ignore the democratic process itself. They find that an understanding of the party system and voting behavior can also be gleaned using more comparative political science approaches. There are clear social bases and policy positions that connect voters to their choice of party, despite the widespread perception that Russian election results are largely predictable and pre-determined.

David White's contribution concludes the volume by examining the significance of the 2016 State Duma election for the integrity and future of the Putin regime. ${ }^{89}$ As noted above, State Duma elections have often performed the role of "primary" elections for the subsequent presidential contests. The successful execution of UR's victory, and the continued compliance of the parliamentary opposition, mean that the 2016 campaign gave some reassurance to the Kremlin. But White's discussion of the election goes deeper, into the nature of the regime. He contrasts the role that elections play in electoral authoritarian regimes - bolstering legitimacy through mass mobilization - with the fact that 2016 election balanced just the right amount of openness and restriction to maximize the electoral outcomes whilst minimizing the potential dangers for the ruling elite. In other words, the de-mobilization strategy pursued by the Kremlin in 2016 may have marked a significant shift in emphasis towards the consolidation of power rather than the demonstration of support. In essence, his article ends the volume with the same central question as this one began with - about what role that the 2016 State Duma election played in sustaining the current regime in power.

\footnotetext{
${ }^{89}$ David White, “Modifying Electoral Authoritarianism: What the 2016 Parliamentary Elections Tell Us About the Nature and Resilience of the Putin Regime”, Russian Politics 2, no. 4 (2017): XXX-XXX.
} 